\title{
Oxygen-Induced Tension in the Sheep Ductus Arteriosus: Effects of Gestation on Potassium and Calcium Channel Regulation
}

\author{
NAHID WALEH, JEFF REESE, HIROKI KAJINO, CHRISTINE ROMAN, STEVEN SEIDNER, DONALD MCCURNIN, \\ AND RONALD I. CLYMAN
}

\begin{abstract}
Department of Pediatrics [H.K., C.R., R.I.C.], University of California, San Francisco, San Francisco, California 94143; Pharmaceutical Discovery Division [N.W.], SRI International, Menlo Park, California 94025; Department of Pediatrics [J.R.], Vanderbilt University, Nashville, Tennessee 37232; Department of Pediatrics [S.S., D.M.], University of Texas, Health Science Center, San Antonio, Texas 78229; Southwest Foundation for Biomedical Research [D.M.], San Antonio, Texas 78227
\end{abstract}

\begin{abstract}
Compared with the full-term ductus arteriosus, the premature ductus is less likely to constrict when exposed to postnatal oxygen concentrations. We used isolated fetal sheep ductus arteriosus (pretreated with inhibitors of prostaglandin and nitric oxide production) to determine whether changes in $\mathrm{K}^{+}$- and $\mathrm{Ca}_{\mathrm{L}}$-channel activity could account for the developmental differences in oxygen-induced tension. In the mature ductus, $\mathrm{K}_{\mathrm{V}}$-channels appear to be the only $\mathrm{K}^{+}$-channels that oppose ductus tension. Oxygen concentrations between ( $2 \%$ and $15 \%$ ) inhibit $\mathrm{K}_{\mathrm{V}}$-channel activity, which increases the $\mathrm{Ca}_{\mathrm{L}}$-channel-mediated increase in tension. Low oxygen concentrations have a direct inhibitory effect on $\mathrm{Ca}_{\mathrm{L}}$-channel activity in the immature ductus; this is not the case in the mature ductus. In the immature ductus, three different $\mathrm{K}^{+}$-channel activities $\left(\mathrm{K}_{\mathrm{V}}, \mathrm{K}_{\mathrm{Ca}}\right.$, and $\mathrm{K}_{\mathrm{ATP}}$ ) oppose ductus tension and contribute to its decreased tone. Oxygen inhibits the activities of all three $\mathrm{K}^{+}$-channels. The inhibitory effects of the three $\mathrm{K}^{+}$-channel activities decline with advancing gestation. The decline in $\mathrm{K}^{+}$-channel activity is not due to decreased $\mathrm{K}^{+}$-channel expression. Super-physiologic oxygen concentrations $\left(\geq 30 \% \mathrm{O}_{2}\right.$ ) constrict the ductus by using calcium-dependent pathways that are independent of $\mathrm{K}^{+}$- and $\mathrm{Ca}_{\mathrm{L}}$-channel activities. Superphysiologic oxygen concentrations eliminate the difference in tensions between the two age groups. (Pediatr Res 65: 285-290, 2009)
\end{abstract}

$\mathrm{T}$ he postnatal increase in arterial $\mathrm{PaO}_{2}$ plays an important role in ductus arteriosus constriction after birth. In the late gestation fetus, the changes in tension that accompany changes in oxygen concentration (within the physiologic range) appear to be due to changes in calcium entry through the ductus smooth muscle $\mathrm{Ca}_{\mathrm{L}}$ channels $(1,2)$. The $\mathrm{Ca}_{\mathrm{L}}$ channels are regulated by the smooth muscle's membrane potential; calcium enters the cells when the cells are depolarized. $\mathrm{K}^{+}$-channels and $\mathrm{Na}^{+}-\mathrm{K}^{+}$-ATPases are the main determinants of the smooth muscle's membrane potential. A decrease in $\mathrm{K}^{+}$-channel activity, due to $\mathrm{K}^{+}$-channel blockade and/or down-regulation of channel expression, leads to membrane de-

Received August 13, 2008; accepted October 24, 2008.

Correspondence: Ronald Clyman, M.D., University of California San Francisco, 513 Parnassus Ave., Room 1408 HSW, UCSF Box 0544, San Francisco, CA 94143-0544; e-mail: clymanr@peds.ucsf.edu

Supported by grants from U.S. Public Health Service (NIH grants HL46691, HL56061, HL77395, HL52636 BPD Resource center and P51RR13986 baboon facility support) and by a gift from the Jamie and Bobby Gates Foundation.

Dr. Kajino is currently at the Department of Pediatrics, Asahikawa Medical College, Hokkaido, Japan. polarization. Oxygen appears to inhibit $\mathrm{K}^{+}$-channel activity, leading to smooth muscle depolarization and increased calcium entry through the voltage-dependent $\mathrm{Ca}_{\mathrm{L}}$-channels $(1,3,4)$.

Most studies suggest that voltage-gated $\mathrm{K}^{+}$-channels $\left(\mathrm{K}_{\mathrm{V}}\right.$ channels) are responsible for oxygen's effect on membrane depolarization (3-5); ATP-sensitive $\mathrm{K}^{+}$-channels $\left(\mathrm{K}_{\mathrm{ATP}}\right.$ channels) and large conductance calcium-and-voltage sensitive $\mathrm{K}^{+}$-channels $\left(\mathrm{K}_{\mathrm{Ca}}\right.$ channels) have also been implicated as oxygen sensors $(1,6)$. At the molecular level, $\mathrm{K}^{+}$-channels are composed of pore-forming $\alpha$-subunits, which co-assemble with cytoplasmic regulatory/auxiliary $\beta$-subunits. Both $\mathrm{K}_{\mathrm{V}}$ $\alpha$-subunits (Kv1.2, Kv1.5, Kv2.1, Kv3.1, Kv4.2, Kv4.3, and $\mathrm{Kv} 9.3$ ) and $\mathrm{K}_{\mathrm{V}} \beta$-subunits have been shown to have oxygensensing capabilities (7). $\mathrm{K}_{\mathrm{ATP}}$ channels [composed of $\mathrm{K}_{\mathrm{IR}} 6$ $\alpha$-subunits and a sulfonylurea receptor (SUR2)] are responsive to hypoxic conditions and changes in oxygen concentration $(8,9)$. $\mathrm{K}_{\mathrm{Ca}}$ channels (composed of $\mathrm{BK}_{\mathrm{Ca}} \alpha$-subunits and $\beta 1$ subunits) can be modulated by hypoxia and oxidant stress $(6,9,10)$.

In contrast with the full-term ductus, the premature ductus is less likely to constrict when exposed to physiologic oxygen concentrations (11). Super-physiologic arterial oxygen concentrations, conversely, produce the same degree of constriction in vivo in the immature ductus as is observed in the mature ductus (11).

In this study, we used fetal sheep, to determine whether changes in $\mathrm{K}^{+}$- and $\mathrm{Ca}_{\mathrm{L}}$ channel function were responsible for the changes in oxygen-induced ductus tension that occur within the physiologic as well as super-physiologic range of oxygen concentrations. We also wanted to determine whether developmental differences in $\mathrm{K}^{+}$-and $\mathrm{Ca}_{\mathrm{L}}$ channel function could account for the differences in tension between the immature and mature ductus. We hypothesized that decreased $\mathrm{K}^{+}$-channel expression would account for the differences in tension between the immature and mature ductus. We used a pharmacologic and quantitative PCR approach to examine the roles of $\mathrm{K}^{+}$-channels and $\mathrm{Ca}_{\mathrm{L}}$ channels in maintaining ductus tensions.

\section{METHODS}

Fifty late-gestation, mature sheep fetuses (mixed Western breed: $137 \pm$ 2 -d gestation, term $=145 \mathrm{~d})$ and 47 immature fetuses $(103 \pm 2 \mathrm{~d})$ were delivered by cesarean section and anesthetized with ketamine $\mathrm{HCl}(30 \mathrm{mg} / \mathrm{kg}$ 
IV) before rapid exsanguination. These procedures were approved by the Committee on Animal Research at the University of California, San Francisco.

The fetal sheep ductus arteriosus was divided into 1-mm-thick rings (two to three rings per animal) and isometric tension was measured in a Krebsbicarbonate solution $\left[\left(\times 10^{-3} \mathrm{M}\right): 118 \mathrm{NaCl}, 4.7 \mathrm{KCl}, 2.5 \mathrm{CaCl}_{2}, 0.9 \mathrm{MgSO}_{4}\right.$, $1 \mathrm{KH}_{2} \mathrm{PO}_{4}, 11.1$ glucose, $\left.23 \mathrm{NaHCO}_{3}(\mathrm{pH} 7.4)\right]$ containing indomethacin $\left(5 \times 10^{-6} \mathrm{M}\right)$ and $\mathrm{N} \omega$-nitro-arginine methyl ester (L-NAME, $\left.10^{-4} \mathrm{M}\right)$, to inhibit endogenous prostaglandin and nitric oxide production, respectively (11). An oxygen electrode placed in the $10-\mathrm{mL}$ organ bath, measured the oxygen concentration. The bath solution was equilibrated with gas mixtures containing $5 \% \mathrm{CO}_{2}$ and was changed every $20 \mathrm{~min}$. Rings were stretched to initial lengths (preterm $=5.2 \pm 0.4 \mathrm{~mm}$; late-gestation $=6.7 \pm 0.6 \mathrm{~mm}$ ) that produce maximal contractile responses when exposed to $\mathrm{K}^{+}$-Krebs solution (containing $0.1 \mathrm{M} \mathrm{KCl}$ substituted for an equimolar amount of $\mathrm{NaCl}$ ), equilibrated with $95 \% \mathrm{O}_{2}(11)$.

Once steady-state tension in $30 \% \mathrm{O}_{2}$ was achieved $(\sim 100-120 \mathrm{~min})$, $\mathrm{K}^{+}$-Krebs solution (equilibrated with $95 \% \mathrm{O}_{2}$ ) was used to measure the maximal contraction that could be developed by the ductus. After returning the rings to the initial modified Krebs solution, equilibrated with $15 \%$ $\mathrm{O}_{2}$, the rings were sequentially exposed to five different oxygen conditions: $2,6,15,30$, and $95 \% \mathrm{O}_{2}$. We refer to bath oxygen concentrations between 2 and $15 \%$ as the "physiologic range" because they produce ductus tissue oxygen concentrations similar to the physiologic extremes experienced in vivo (12) $\left[15 \%\right.$ bath $\mathrm{O}_{2}$ concentration produces tissue oxygen concentrations similar to those achieved during the postnatal increase in arterial $\mathrm{PO}_{2}$; the $2 \%$ bath $\mathrm{O}_{2}$ concentration produces tissue oxygen concentrations similar to those needed to induce remodeling in vivo (11)]. Conversely, we considered the oxygen concentrations between 30 and $95 \%$ as the "super-physiologic range."

After the oxygen dose-response curve, the rings were equilibrated with one of several experimental solutions before repeating the same oxygen doseresponse curve. The solutions included: $10^{-5} \mathrm{M}$ nifedipine $\left(\mathrm{Ca}_{\mathrm{L}}\right.$-channel antagonist), $10^{-6}$ M BAY K8644 ( $\mathrm{Ca}_{\mathrm{L}}$-channel agonist), calcium-free Krebs solution (containing $0.5 \times 10^{-3} \mathrm{M}$ EGTA without calcium), and $\mathrm{K}^{+}$-Krebs solution (to depolarize the muscle). Nifedipine $\left(10^{-5} \mathrm{M}\right)$ inhibits the effects of $10^{-6}$ M BAY K8644 (by $96 \pm 5 \%$ ) and $\mathrm{K}^{+}$-Krebs solution (by $87 \pm 5 \%$ ) when ductus rings are incubated in $15 \% \mathrm{O}_{2}(2)$. Neither $10^{-5} \mathrm{M}$ nifedipine, $10^{-6} \mathrm{M}$ BAY K8644, nor $\mathrm{K}^{+}$-Krebs solution have any effect in the absence of extracellular $\mathrm{Ca}^{++}(2)$.

Ductus were also exposed to $\mathrm{K}^{+}$channel antagonists before the second oxygen dose-response curve: $3 \times 10^{-3} \mathrm{M}$ 4-Aminopyridine $(4 \mathrm{AP})\left(\mathrm{K}_{\mathrm{V}^{-}}\right.$ channel antagonist), $10^{-5} \mathrm{M}$ glibenclamide ( $\mathrm{K}_{\mathrm{ATP}}$ channel antagonist), $50 \times$ $10^{-9} \mathrm{M}$ iberiotoxin ( $\mathrm{K}_{\mathrm{Ca}^{-}}$-channel antagonist), $10^{-3} \mathrm{M}$ tetraethylammonium ion (TEA) ( $\mathrm{K}_{\mathrm{Ca}}$-channel antagonist), $10^{-6} \mathrm{M}$ apamin (small conductance calcium-activated $\mathrm{K}^{+}$-channel antagonist), and $10^{-2} \mathrm{M}$ TEA (which produces $100 \%$ blockade of $\mathrm{K}_{\mathrm{Ca}}$-channels plus $50 \%$ blockade of $\mathrm{Kv}$ and $\mathrm{K}_{\mathrm{ATP}}$ channels). The specificities of the above $\mathrm{K}^{+}$channel antagonists have been reviewed in Ref. 13.

The ductus' contractile response to the oxygen dose-response curve does not change when it is repeatedly exposed in time matched control experiments (11). Sodium nitroprusside, $10^{-3} \mathrm{M}$, was added to each ring at the end of the experiment to determine its minimal tension.

The difference in tensions between any measured steady-state tension and the minimal tension produced by sodium nitroprusside was considered the Net active tension. The difference in tensions between the maximal contraction (produced by $\mathrm{K}^{+}$-Krebs/95\% $\mathrm{O}_{2}$ ) and the minimal tension (with sodium nitroprusside) was treated as the maximal active tension (MAT) capable of being developed by the rings.

Active tensions are expressed as a percentage of the maximal active tension. Maximal active tensions were $16 \pm 2 \mathrm{~g}$ in immature fetuses and $20 \pm$ $3 \mathrm{~g}$ in mature fetuses. The ductus wet weights were as follows: $30 \pm 9 \mathrm{mg}$, immature fetuses; $36 \pm 10 \mathrm{mg}$, mature fetuses. Chemicals were from Sigma Chemical Co. Chemical (St. Louis, MO).

We used the TaqMan Universal PCR master mix of PE Applied Biosystems (Foster City, CA) to quantify the expression of the $\mathrm{K}^{+}$-channel subunits as previously described (14). Total RNA was isolated from the ductus of immature and mature fetal sheep (Table 1) and compared with RNA from the ductus of immature (125-d gestation) and mature (175-d gestation) fetal baboons (Papio sp., full term $=185$-d gestation), and from immature (14-d gestation) and mature (19-d gestation) fetal mice $(C D-1$, full term $=19-d$ gestation) that were delivered by cesarean section and euthanized before breathing.

Statistics. Statistical analyses were performed by the appropriate MannWhitney test, $t$ test, or by analysis of variance. Scheffe's test was used for post hoc analysis. Values are expressed as mean \pm SD.

\section{RESULTS}

Oxygen-induced tension in the mature ductus arteriosus. The late gestation ductus arteriosus developed an active tension that was maintained by extracellular $\mathrm{Ca}^{++}$-dependent and extracellular $\mathrm{Ca}^{++}$-independent pathways (Fig. 1). Oxygen increased ductus tension through a mechanism that depended on the presence of extracellular calcium and could be blocked by high $\mathrm{K}^{+}$-containing Krebs solution (Fig. 1). After the removal of extracellular calcium, both oxygen and elevated $\mathrm{K}^{+}$had only a negligible effect on ductus tension (Fig. 1A).

Only a part of the oxygen-induced increase in ductus tension could be accounted for by changes in $\mathrm{Ca}_{\mathrm{L}}$-channel activity (Fig. $1 B$ ). The $\mathrm{Ca}_{\mathrm{L}}$-channel inhibitor, nifedipine, relaxed the ductus and nearly eliminated oxygen's effect on ductus tension in the physiologic range $\left(2-15 \% \mathrm{O}_{2}\right)$, but only partially inhibited oxygen's effects in the super-physiologic range $\left(\geq 30 \% \mathrm{O}_{2}\right)$. Similarly, BAY K8644, a $\mathrm{Ca}_{\mathrm{L}}$-channel opener, constricted the ductus and prevented oxygen from affecting ductus tension in the physiologic range, but only partially inhibited oxygen's effects in the super-physiologic range (Fig. 1C).

We used a combination of $\mathrm{K}^{+}$-channel inhibitors (4AP/ TEA/glibenclamide), at concentrations that block $\mathrm{K}_{\mathrm{V}}, \mathrm{K}_{\mathrm{Ca}}$, and $\mathrm{K}_{\mathrm{ATP}}$ channel activities (13), to determine whether alterations in $\mathrm{K}^{+}$-channel activity could account for the oxygeninduced changes in ductus tension. Inhibition of $\mathrm{K}^{+}$-channel activity had the same effect on ductus contractility as the $\mathrm{Ca}_{\mathrm{L}}$-channel opener, BAY K8644 (Fig. $2 A$ ). The $\mathrm{K}^{+}$-channel inhibitors blunted the ability of oxygen to affect ductus tension in the physiologic range $\left(2-15 \% \mathrm{O}_{2}\right)$, but only partially inhibited its effects in the super-physiologic range. The selective $\mathrm{K}_{\mathrm{Ca}}$ and $\mathrm{K}_{\mathrm{ATP}}$ inhibitors, iberiotoxin and glibenclamide, had no effect on tension. Only the $\mathrm{K}_{\mathrm{V}}$ inhibitor, $4 \mathrm{AP}$, increased tension and blunted the oxygen-induced response (Fig. 2B, $C$, and $D$ ). These findings are consistent with the hypothesis that, in the mature ductus, most of oxygen's contractile effects (in the physiologic range of oxygen concentrations) can be attributed to decreased $\mathrm{K}_{\mathrm{V}}$-channels activity, which results in subsequent calcium entry through voltage-gated $\mathrm{Ca}_{\mathrm{L}}$-channels; conversely, at super-physiologic oxygen concentrations, oxygen appears to use additional mechanisms that depend on extracellular calcium entry but are independent of $\mathrm{K}_{\mathrm{V}}$-channel and $\mathrm{Ca}_{\mathrm{L}}$-channel activities.

Oxygen-induced tension in the immature ductus arteriosus. The immature ductus also develops an active tension that is maintained by extracellular $\mathrm{Ca}^{++}$-dependent and $\mathrm{Ca}^{++}$independent pathways. Extracellular $\mathrm{Ca}^{++}$-dependent pathways appear to play a smaller role in maintaining tension in the physiologic range of oxygen concentrations, in the immature ductus, than they do in the mature ductus (compare Figs. $1 A$ and $3 A$ ). As the immature ductus becomes hypoxic, pathways that depend on extracellular $\mathrm{Ca}^{++}$no longer appear to play a significant role in maintaining ductus tension. This appears to be due to a direct effect of low oxygen concentrations on $\mathrm{Ca}_{\mathrm{L}}$-channel activity. Conditions that usually open or close $\mathrm{Ca}_{\mathrm{L}}$-channels have either no effect (BAY K8644 and nifedipine) or a blunted effect $\left(\mathrm{K}^{+}\right.$-Krebs solution) on tone at $2 \% \mathrm{O}_{2}$ (Fig. 3). This contrasts with the mature ductus, where 
Table 1. Expression of K-channel subunits in the mature and immature ductus arteriosis

\begin{tabular}{|c|c|c|c|c|c|c|c|}
\hline \multirow[b]{2}{*}{ Gene } & \multirow[b]{2}{*}{ Gestation } & \multicolumn{2}{|c|}{$\begin{array}{c}\text { Sheep } \\
\Delta \mathrm{CT}(\text { MDH-gene })\end{array}$} & \multicolumn{2}{|c|}{$\begin{array}{c}\text { Baboon } \\
\Delta \mathrm{CT}(\mathrm{MDH}-\text { gene })\end{array}$} & \multicolumn{2}{|c|}{$\begin{array}{c}\text { Mouse } \\
\Delta \mathrm{CT}(\mathrm{MDH}-\text { gene })\end{array}$} \\
\hline & & Mean & $(\mathrm{Sd})$ & Mean & (sd) & Mean & $(\mathrm{sd})$ \\
\hline \multirow[t]{2}{*}{$\mathrm{Kv} 1.2$} & Immature & -8.0 & $(0.8)$ & -3.3 & (1.3) & -3.9 & $(0.4)$ \\
\hline & $\begin{array}{l}\text { Mature } \\
\mathrm{p}<0.05\end{array}$ & $\begin{array}{c}-5.6 \\
\uparrow\end{array}$ & $(0.9)$ & $\begin{array}{c}-1.1 \\
\uparrow\end{array}$ & $(0.9)$ & $\begin{array}{c}-4.8 \\
\downarrow\end{array}$ & $(0.4)$ \\
\hline \multirow[t]{2}{*}{$\mathrm{Kv} 1.5$} & Immature & -7.6 & (1.5) & 1.2 & $(0.2)$ & -3.6 & $(0.2)$ \\
\hline & $\begin{array}{l}\text { Mature } \\
\mathrm{p}<0.05\end{array}$ & $\begin{array}{c}-4.5 \\
\uparrow\end{array}$ & $(0.5)$ & $\begin{array}{l}0.7 \\
\downarrow\end{array}$ & $(0.2)$ & $\begin{array}{c}-3.2 \\
\uparrow\end{array}$ & $(0.3)$ \\
\hline \multirow[t]{2}{*}{ Kv2.1 } & Immature & -4.0 & (0.6) & -3.8 & $(0.8)$ & -4.7 & $(0.3)$ \\
\hline & $\begin{array}{l}\text { Mature } \\
\mathrm{p}<0.05\end{array}$ & $\begin{array}{c}-3.0 \\
\uparrow\end{array}$ & $(0.2)$ & $\begin{array}{c}-\mathbf{3 . 0} \\
\uparrow\end{array}$ & $(0.5)$ & $\begin{array}{c}-3.6 \\
\uparrow\end{array}$ & $(0.8)$ \\
\hline \multirow[t]{2}{*}{ Kv9.3 } & Immature & -6.6 & (1.4) & -6.5 & (1.6) & -1.5 & $(0.3)$ \\
\hline & $\begin{array}{l}\text { Mature } \\
\mathrm{p}<0.05\end{array}$ & $\begin{array}{c}-4.2 \\
\uparrow\end{array}$ & $(0.9)$ & $\begin{array}{c}-4.7 \\
\uparrow\end{array}$ & (1.0) & $\begin{array}{c}-1.6 \\
-\end{array}$ & $(0.4)$ \\
\hline \multirow[t]{2}{*}{$\mathrm{Kv} \beta 1.2$} & Immature & -11 & $(0.5)$ & -5.1 & $(1.2)$ & -3.9 & $(0.3)$ \\
\hline & $\begin{array}{l}\text { Mature } \\
\mathrm{p}<0.05\end{array}$ & $\begin{array}{r}-11 \\
-\end{array}$ & (1.0) & $\begin{array}{c}-\mathbf{3 . 3} \\
\uparrow\end{array}$ & $(0.8)$ & $\begin{array}{c}-3.9 \\
-\end{array}$ & (0.6) \\
\hline \multirow[t]{2}{*}{$\mathrm{Kv} \beta 1.3$} & Immature & -2.6 & $(0.5)$ & $-\mathbf{3 . 0}$ & $(1.2)$ & -1.5 & $(0.2)$ \\
\hline & $\begin{array}{l}\text { Mature } \\
\mathrm{p}<0.05\end{array}$ & $\begin{array}{c}-1.3 \\
\uparrow\end{array}$ & (0.3) & $\begin{array}{c}-1.2 \\
\uparrow\end{array}$ & $(0.8)$ & $\begin{array}{c}-2.0 \\
\downarrow\end{array}$ & $(0.3)$ \\
\hline \multirow[t]{2}{*}{$\mathrm{K}_{\mathrm{IR}} 6.1$} & Immature & -6.3 & $(0.3)$ & -1.7 & $(1.0)$ & -4.3 & $(0.4)$ \\
\hline & $\begin{array}{l}\text { Mature } \\
\mathrm{p}<0.05\end{array}$ & $\begin{array}{c}-5.7 \\
\uparrow\end{array}$ & (0.3) & $\begin{array}{c}-2.0 \\
-\end{array}$ & (1.0) & $\begin{array}{c}-2.4 \\
\uparrow\end{array}$ & $(0.7)$ \\
\hline \multirow[t]{2}{*}{ SUR2 } & Immature & -4.0 & $(0.2)$ & -0.8 & $(0.2)$ & -6.5 & $(0.5)$ \\
\hline & $\begin{array}{l}\text { Mature } \\
\mathrm{p}<0.05\end{array}$ & $\begin{array}{c}-3.3 \\
\uparrow\end{array}$ & (0.3) & $\begin{array}{c}-1.2 \\
\downarrow\end{array}$ & $(0.2)$ & $\begin{array}{c}-3.2 \\
\uparrow\end{array}$ & $(0.4)$ \\
\hline \multirow[t]{3}{*}{$\mathrm{BK}_{\mathrm{Ca}}$} & Immature & -9.0 & $(0.3)$ & -1.8 & $(0.3)$ & -10.6 & $(0.6)$ \\
\hline & Mature & -8.6 & $(0.4)$ & -1.8 & $(0.3)$ & -9.5 & $(0.9)$ \\
\hline & $\mathrm{p}<0.05$ & - & & - & & - & \\
\hline \multirow[t]{3}{*}{$\mathrm{BK}_{\mathrm{Ca}} \beta 1$} & Immature & -2.6 & $(0.3)$ & -0.5 & $(0.3)$ & -4.8 & $(0.6)$ \\
\hline & Mature & -1.2 & $(0.4)$ & 0.1 & $(0.3)$ & -3.7 & $(0.9)$ \\
\hline & $\mathrm{p}<0.05$ & $\uparrow$ & & $\uparrow$ & & $\uparrow$ & \\
\hline
\end{tabular}

Real Time polymerase chain reaction (PCR) measurements of $\mathrm{K}^{+}$-channel subunits in the mature and immature ductus arteriosus of sheep, baboons and mice. $\triangle \mathrm{CT}(\mathrm{MDH}-\mathrm{gene})$ represents the difference in cycle threshold (CT) between the expression of the housekeeping gene Malate dehydrogenase (MDH) and the gene of interest. Each unit of $\triangle \mathrm{CT}(\mathrm{MDH}$-gene) represents a 2-fold increase in a gene's mRNA. The more negative the $\Delta \mathrm{CT}(\mathrm{MDH}$-gene), the fewer the number of starting copies of a gene (mRNA). Number of separate animals used: sheep (immature $=7$, mature $=7$ ); baboon (immature $=10$, mature $=10$ ); mouse litters (immature $=10$, mature $=9$ ). From each litter of mice we obtained between 10-12 ductus. $\uparrow p<0.05$, mature significantly greater than immature; $\downarrow p<0.05$, mature significantly less than immature; $-p>0.05$, mature not significantly different from immature.
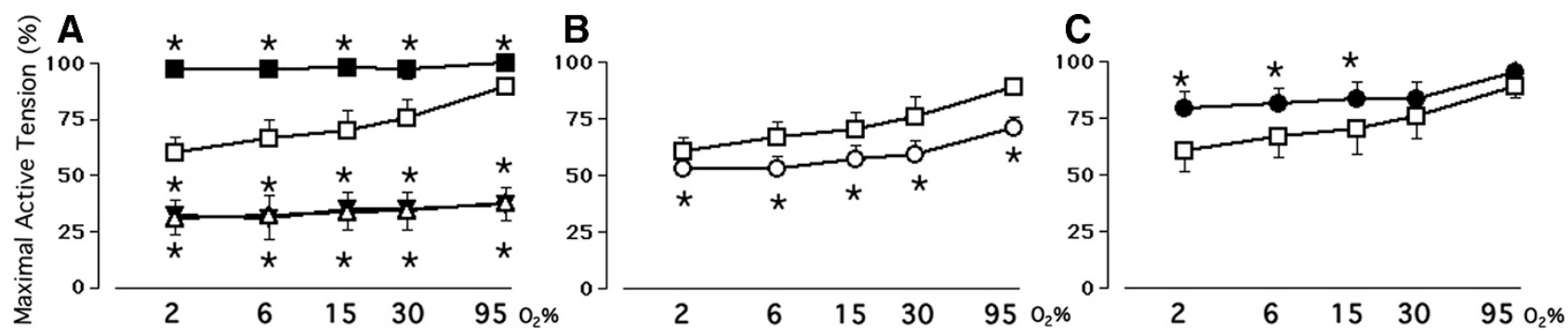

Figure 1. Effects of oxygen on active tension in the mature ductus arteriosus. Values represent active tension (mean \pm SD) as a percent of maximal active tension. $n=$ number of ductus rings from separate animals. Ductus were studied in the presence or absence of Panel A: Krebs solution (Control, $\square$, $n=10)$, High $\mathrm{K}^{+}$-Krebs solution $(\boldsymbol{\square}, n=8)$, calcium-free Krebs solution $(\triangle, n=10)$, or calcium-free/High $\mathrm{K}^{+}-$Krebs solution $(\boldsymbol{\nabla}, n=8)$; Panel B: $10^{-5} \mathrm{M}$ nifedipine $(\bigcirc, n=10)$; Panel C: $10^{-6}$ M BAY K8644 $(\mathbf{\bullet}, n=7)$. ${ }^{*} p<0.05$, experimental condition $v$ Control $(\square)$. Ductus tension at $6,15,30$, and $95 \%$ O differed significantly $(p<0.05)$ from the tension at $2 \% \mathrm{O}_{2}$, except for rings incubated in High $\mathrm{K}^{+}$-Krebs solution where tensions at $6,15,30$, and $95 \% \mathrm{O}_{2}$ were not significantly different from those at $2 \% \mathrm{O}_{2}$; and in calcium-free Krebs, in calcium-free/High $\mathrm{K}^{+}$-Krebs solution, in nifedipine, and in BAY K8644 where tensions at $6 \% \mathrm{O}_{2}$ were not significantly different from those at $2 \% \mathrm{O}_{2}$.

a significant proportion of the tension in $2 \% \mathrm{O}_{2}$ is maintained by pathways that depend on the presence of extracellular $\mathrm{Ca}^{++}$, and the effects of nifedipine, BAY K8644 and High- $\mathrm{K}^{+}$solution are minimally affected by changes between 2 and $30 \% \mathrm{O}_{2}$ (Fig. 1).
We next examined the extent to which $\mathrm{K}^{+}$-channel activity affected tension in the immature and mature ductus. To account for the effect of low oxygen concentrations on the maximal tension that can be produced by $\mathrm{K}^{+}-$Krebs solution in the immature ductus (Fig. 3A), we expressed the net active tension (at a 

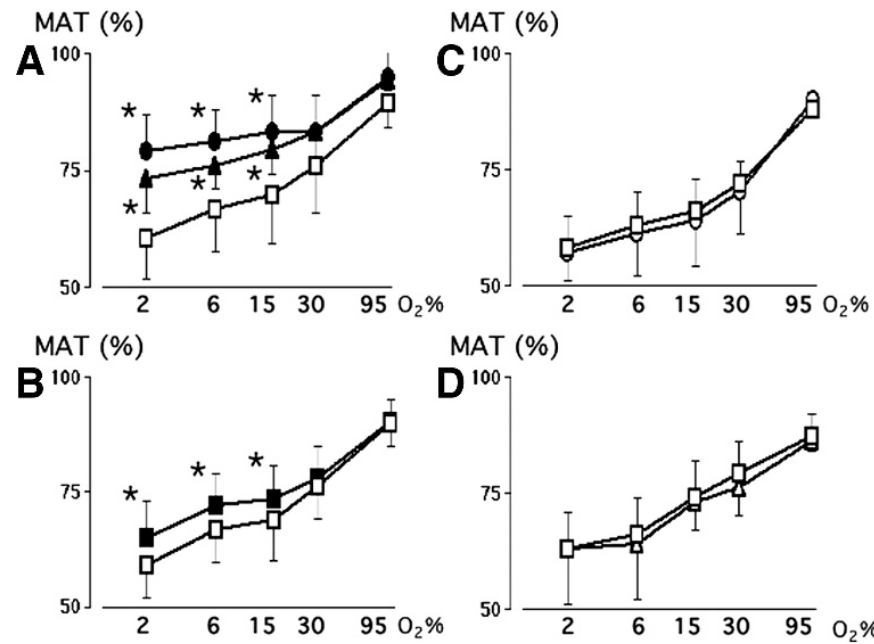

MAT (\%)
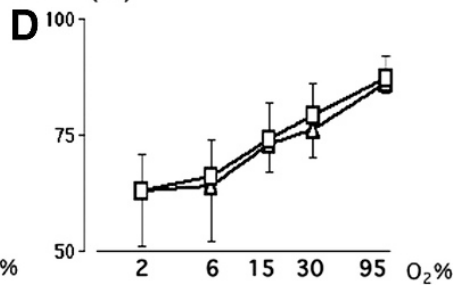

Figure 2. Effects of oxygen on active tension in the mature ductus arteriosus. Ductus were studied in the presence or absence of Panel A: $10^{-6} \mathrm{M}$ BAY $\mathrm{K} 8644(\bullet)$ or $\left(3 \times 10^{-3} \mathrm{M} 4 \mathrm{Ap}+10 \times 10^{-3} \mathrm{M}\right.$ TEA $+10^{-5} \mathrm{M}$ glibenclamide) (4AP/TEA/Glib) $(\boldsymbol{\Lambda}, n=7)$; Panel B: $3 \times 10^{-3} \mathrm{M} 4 \mathrm{AP}(\boldsymbol{\square}$, $n=7)$; Panel $C: 50 \times 10^{-9} \mathrm{M}$ iberiotoxin $(\bigcirc, n=5)$; Panel $D: 10^{-5} \mathrm{M}$ glibenclamide $(\triangle, n=6)$. $* p<0.05$, experimental condition $v s$ Control $(\square)$. Ductus tension at $6,15,30$, and $95 \% \mathrm{O}_{2}$ differed significantly $(p<0.05)$ from the tension at $2 \% \mathrm{O}_{2}$, except for rings incubated with BAY K8644 and rings incubated with 4AP/TEA/glibenclamide, where tensions at $6 \% \mathrm{O}_{2}$ were not significantly different from those at $2 \% \mathrm{O}_{2}$.

particular oxygen concentration) as a percentage of the net active tension produced by $\mathrm{K}^{+}$-Krebs solution at that particular oxygen concentration (Fig. 4).

Tensions in the immature ductus (incubated under Control conditions, at oxygen concentrations between 2 and $15 \% \mathrm{O}_{2}$ ) were significantly less than those in the mature ductus (Fig. $4 A$ ). Inhibition of $\mathrm{K}^{+}$-channel activity, with 4AP/TEA/ glibenclamide, increased tension in both the mature and immature ductus and eliminated the difference in tension between the two age groups (Fig. 4A).

In contrast with the mature ductus, where only the $\mathrm{K}_{\mathrm{V}}$ channel inhibited tension (Fig. $2 B, C$, and $D$ ), tension in the immature ductus was inhibited by three types of $\mathrm{K}^{+}$-channels $\left(\mathrm{K}_{\mathrm{V}}, \mathrm{K}_{\mathrm{Ca}}\right.$, and $\mathrm{K}_{\mathrm{ATP}}$ channels). In the immature ductus, $\mathrm{K}_{\mathrm{V}}$, $\mathrm{K}_{\mathrm{Ca}}$, and $\mathrm{K}_{\mathrm{ATP}}$ channel inhibitors blunted the effects of physiologic oxygen concentrations on ductus contractility (Fig. $4 A-D$ ). The $\mathrm{K}^{+}$channel inhibitors did not prevent oxygen from constricting the immature ductus at super-physiologic oxygen concentrations (Fig. 4A). Apamin had no effect on either the immature or mature ductus (data not shown).

The inhibitory effects of $\mathrm{K}_{\mathrm{V}}, \mathrm{K}_{\mathrm{Ca}}$, and $\mathrm{K}_{\mathrm{ATP}}$ channels on contractility appeared to decline with advancing gestation because their selective antagonists were less effective in the mature compared with the immature ductus (Figs. 2 and 4). Their declining role was not due to decreased expression of $\mathrm{K}^{+}$-channel $\alpha$ - and $\beta$ - subunits because their expression was either the same (BKCa) or higher (Kv1.2, Kv1.5, Kv 2.1, Kv 9.3, $\mathrm{K}_{\mathrm{IR}} 6.1, \mathrm{Kv} \beta 1.3, \mathrm{SUR} 2$, and $\left.\mathrm{BK}_{\mathrm{Ca}} \beta 1\right)$ in the mature sheep ductus (Table 1).

Developmental changes in $\mathrm{K}^{+}$-channel $\alpha$ - and $\beta$-subunit expression also occurred in the baboon and mouse ductus; however, there was no consistent pattern of change in $\mathrm{K}^{+}$- channel expression across the species (Table 1). The Kv2.1 and the $\mathrm{BK}_{\mathrm{Ca}} \beta 1$ subunits were the only channel subunits that changed their expression in the same direction (increase) with advancing gestation (Table 1).

\section{DISCUSSION}

Effects of physiologic and super-physiologic oxygen concentrations on the mature ductus. The ductus arteriosus develops an active tension that consists of both extracellular $\mathrm{Ca}^{++}$-dependent and extracellular $\mathrm{Ca}^{++}$-independent components. Recent reports suggest that the extracellular $\mathrm{Ca}^{++}-$ independent component of ductus tension may be due to rho kinase or tyrosine kinase-mediated $\mathrm{Ca}^{++}$sensitization: a process whereby constriction occurs, independent of ongoing increases in cytosolic $\mathrm{Ca}^{++}(2,15-17)$. However, the changes in ductus tension that occur with changes in oxygen concentration appear to be mediated by pathways that regulate the entry of extracellular calcium into the ductus wall; removal of extracellular $\mathrm{Ca}^{++}$eliminates the ability of oxygen to alter ductus tension (Fig. 1A).

In the late gestation fetus (in the absence of prostaglandin and nitric oxide production), changes in $\mathrm{Ca}_{\mathrm{L}}$-channel activity appear to be responsible for the changes in ductus tension that occur when oxygen concentrations are varied between 2 and $15 \% \mathrm{O}_{2}$ (the physiologic range) (Fig. 1). The effects of physiologic oxygen concentrations on ductus tension are blunted by the removal of extracellular calcium, or the presence of $\mathrm{Ca}_{\mathrm{L}}$-channel inhibitors or activators (Fig. 1). In addition, the effects of physiologic oxygen concentrations on ductus tension appear to be because of their ability to inhibit $\mathrm{K}^{+}$-channel activity (Fig. $2 A$ ). Our observations are consistent with prior studies that found that oxygen increased $\mathrm{Ca}^{++}$ entry through voltage-dependent $\mathrm{Ca}_{\mathrm{L}}$-channels, by inhibiting $\mathrm{K}^{+}$channel activity and depolarizing ductus smooth muscle $(1,3,4,18,19)$.

Oxygen concentrations above the physiologic range $(\geq 30 \%$ $\mathrm{O}_{2}$, the super-physiologic range) appear to inhibit most of the ductus' $\mathrm{K}^{+}$-channel activity because $\mathrm{K}^{+}$-channel inhibitors no longer affect ductus tension (Fig. 2). Although oxygen concentrations in the super-physiologic range eliminate the ability of $\mathrm{K}^{+}$-channel inhibitors to affect ductus tension, the converse is not the case; $\mathrm{K}^{+}$-channel inhibitors only partially inhibit oxygen's contractile effects in the super-physiologic range. Similarly, the $\mathrm{Ca}_{\mathrm{L}}$-channel opener, BAY K8644, and the $\mathrm{Ca}_{\mathrm{L}}$-channel blocker, nifedipine, only partially inhibit oxygen's effects in the super-physiologic range (Fig. 1). Therefore, additional extracellular $\mathrm{Ca}^{++}$-dependent mechanisms that are independent of $\mathrm{K}^{+}$- and $\mathrm{Ca}_{\mathrm{L}}$-channel activities, must affect ductus tension when oxygen concentrations increase above $30 \% \mathrm{O}_{2}$. We speculate that these may involve other depolarization-sensitive calcium channels (like T-type channels) rather than mechanisms that alter $\mathrm{Ca}^{++}$sensitivity: both high $\mathrm{K}^{+}$and low $\mathrm{Ca}^{++}$containing solutions block the effects of super-physiologic oxygen concentrations on ductus tension, whereas inhibitors of rho kinase and tyrosine kinase do not prevent super-physiologic oxygen concentrations from contracting the ductus (data not shown). 

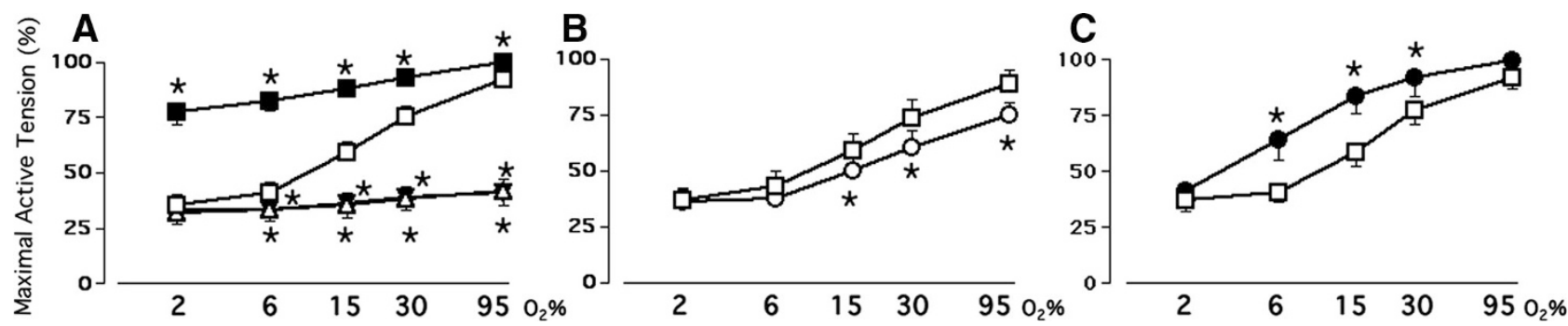

Figure 3. Effects of oxygen on active tension in the immature ductus arteriosus. Ductus were studied in the presence or absence of Panel A: Krebs solution (Control, $\square, n=13), \mathrm{K}^{+}$-Krebs solution $(\boldsymbol{\square}, n=13)$, calcium-free Krebs solution $(\triangle, n=13)$, or calcium-free/High $\mathrm{K}^{+}$-Krebs solution $(\boldsymbol{\nabla}, n=13)$; Panel $B$ : nifedipine $(\mathrm{O}, n=12)$; Panel C: BAY K8644 $(\bullet, n=12)$. * $p<0.05$, experimental condition $v$ s Control $(\square)$. Ductus tension at $6,15,30$, and $95 \% \mathrm{O}_{2}$ differed significantly $(p<0.05)$ from the tension at $2 \% \mathrm{O}_{2}$, except for rings incubated with calcium-free Krebs solution, in calcium-free/High $\mathrm{K}^{+}-\mathrm{Krebs}$ solution, and in nifedipine where tensions at $6 \% \mathrm{O}_{2}$ were not significantly different from those at $2 \% \mathrm{O}_{2}$.
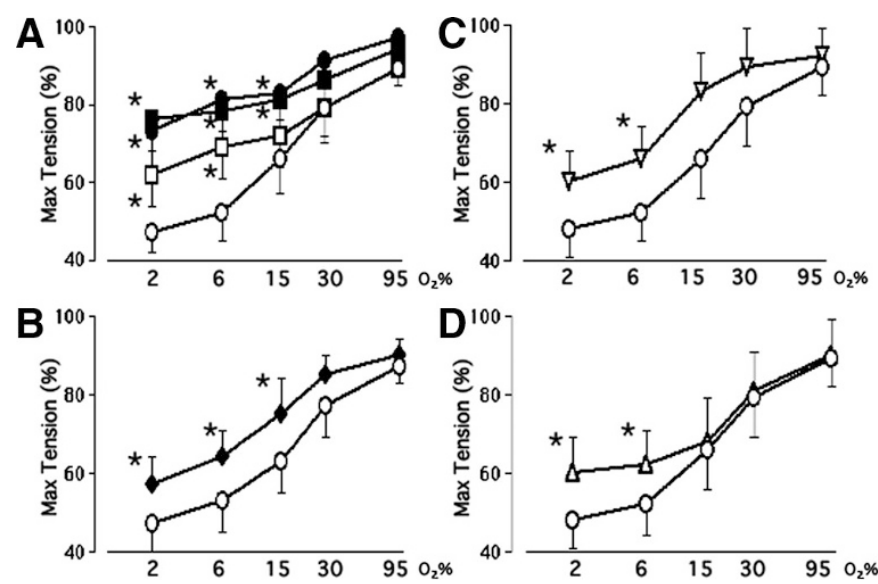

Figure 4. Effects of oxygen and $\mathrm{K}^{+}$-channel inhibitors in the mature and immature ductus arteriosus. Values represent ductus tension (mean $\pm \mathrm{SD}$ ) (at a particular oxygen concentration) expressed as a percent of the net active tension produced by $\mathrm{K}^{+}$-Krebs solution at that particular oxygen concentration (Max Tension). Panel A: Ductus from mature $(n=7)$ and immature $(n=$ 9) fetuses were studied in the presence or absence of $4 \mathrm{AP} / \mathrm{TEA} / \mathrm{glibenclamide}$ (Glib). Tensions in immature ductus, under Control $(\bigcirc)$ conditions (at 2 and $6 \% \mathrm{O}_{2}$ ) differed significantly $(p<0.05)$ from tensions in mature ductus under Control $(\square)$ conditions; the tensions at higher oxygen concentrations $(15,30$, and $95 \% \mathrm{O}_{2}$ ) were not significantly different between the immature and mature ductus under Control conditions. When the rings were incubated in 4AP/TEA/glibenclamide, immature ductus ( ) developed the same tensions as mature ductus ( $\square$ ). Panel B: Immature ductus were studied in the absence $(\bigcirc)$ or presence $(\checkmark)$ of $4 \mathrm{AP}(n=7)$; Panel $C$ : Immature ductus were studied in the absence $(\bigcirc)$ or presence $(\checkmark)$ of iberiotoxin $(n=6)$; Panel $D$ : Immature ductus were studied in the absence $(\bigcirc)$ or presence $(\triangle)$ of glibenclamide (Glib, $n=6$ ). * $p<0.05$, experimental condition vs Immature Control. Ductus tension at $6,15,30$, and $95 \% \mathrm{O}_{2}$ differed significantly $(p<0.05)$ from the tension at $2 \% \mathrm{O}_{2}$, except for rings incubated in 4AP/TEA/glibenclamide, where tensions at $6 \% \mathrm{O}_{2}$ were not significantly different from those at $2 \% \mathrm{O}_{2}$.

Effects of physiologic oxygen concentrations on the immature ductus. When oxygen concentrations are in the physiologic range, the tensions developed by the immature ductus are significantly less than those developed by the mature ductus (Figs. $1 A$ and $3 A)(2,11)$. Our studies suggest that the major factor responsible for the difference in tensions between the immature and mature ductus is the way the immature ductus processes extracellular $\mathrm{Ca}^{++}$. In the absence of extracellular $\mathrm{Ca}^{++}$, the tension in the mature ductus drops to the same level as the immature ductus ( $32 \pm 6 \%$ MAT) (Figs. $1 \mathrm{~A}$ and $3 A$ ).

In the physiologic range of oxygen concentrations, oxygen affects the immature ductus' tension both by affecting the influx of extracellular calcium (Fig. 3) and by altering $\mathrm{K}^{+}$channel activity (Fig. 4). The inhibitory effects of low oxygen concentrations on calcium entry appear to be limited to their effects on $\mathrm{Ca}_{\mathrm{L}}$-channels; low oxygen concentrations do not alter the contractile effects of agonists that increase intracellular calcium through pathways that are independent of $\mathrm{Ca}_{\mathrm{L}^{-}}-$ channels (2).

The differences in tensions between the immature and mature ductus also appear to be due to differences in $\mathrm{K}^{+}$ channel activity. Inhibition of $\mathrm{K}^{+}$-channel activity, with 4AP/ TEA/glibenclamide, increased ductus tension in both the mature and immature ductus and eliminated the difference in tensions between the two age groups (Fig. 4A). Three $\mathrm{K}^{+}$channels $\left(\mathrm{K}_{\mathrm{V}}, \mathrm{K}_{\mathrm{Ca}}\right.$, and $\left.\mathrm{K}_{\mathrm{ATP}}\right)$ appear to play a role in inhibiting tension in the immature ductus (Fig. $4 B, C$, and $D$ ). The inhibitory effects of the $\mathrm{K}_{\mathrm{Ca}}$, and $\mathrm{K}_{\mathrm{ATP}}$ channels appear to decline with advancing gestation, because their selective antagonists have less of an effect on ductus tension as the fetus matures (compare Figs. $2 B-D$ and $4 B-D$ ). The declining effects of $\mathrm{K}^{+}$-channel activity on ductus contractility is not due to decreased expression of $\mathrm{K}^{+}$-channel $\alpha$ - or $\beta$-subunits because their expression is increased, if anything, with advancing gestation (Table 1).

Effects of super-physiologic oxygen concentrations on the immature ductus. When oxygen concentrations increase into the super-physiologic range, in the immature ductus, the inhibitory effects of the $\mathrm{K}_{\mathrm{V}}, \mathrm{K}_{\mathrm{Ca}}$, and $\mathrm{K}_{\mathrm{ATP}}$ channels appear to be blocked because their respective inhibitors (4AP, iberiotoxin, and glibenclamide) no longer have any effect on ductus contractility (Fig. 4). Whether the effects of super-physiologic oxygen concentrations are mediated through changes in the $\mathrm{K}^{+}$-channels themselves or through changes in commonly shared downstream pathways will have to await the results of future electrophysiological studies.

Super-physiologic oxygen concentrations eliminate the difference in tensions between the mature and immature ductus (Fig. 4A). These results may explain why super-physiologic arterial oxygen concentrations are able to constrict the immature ductus to the same degree as the mature ductus, in vivo (11).

Oxygen responsiveness in the immature ductus and $\mathrm{Kv}$ channel expression. Prior studies, in rabbits, suggest that reduced expression of the oxygen-sensitive $\mathrm{K}_{\mathrm{V}}$-channel $\alpha$-subunits, $\mathrm{Kv} 1.5$ and $\mathrm{Kv} 2.1$, lead to impaired oxygeninduced constriction in the immature ductus (4). In these 
studies, ex vivo transfer of the genes for Kv1.5 or Kv2.1 into the immature ductus partially rescued the contractile response to oxygen (4). In contrast, a recent study, performed in rats, found exactly the opposite results [i.e. expression of $\mathrm{K}_{\mathrm{V}}$ $\alpha$-subunits was greater in the immature than the mature ductus (20)]. We examined the developmental expression of several $\mathrm{K}_{\mathrm{V}}$-channel $\alpha$-subunits in sheep, baboon, and mouse ductus to determine whether decreased $\mathrm{K}_{\mathrm{V}}$-channel $\alpha$-subunit expression could lead to impaired oxygen-induced constriction in other species. The expression of several of the $\mathrm{K}_{\mathrm{V}} \alpha$-subunits was reduced in the immature ductus in each of the species; however, only the Kv2.1 $\alpha$-subunit was consistently reduced in all three species (Table 1).

Although decreased $\mathrm{K}_{\mathrm{V}} \alpha$-subunit expression may lead to decreased oxygen-induced constriction in the immature rabbit ductus (4), it did not lead to a decreased contractile response to oxygen in the immature sheep ductus. In fact, changes in oxygen concentration (in the physiologic range) produced larger changes in tension in the immature ductus than in the mature ductus (Fig. 4A: Immature Control versus Mature Control). In addition, $\mathrm{K}^{+}$-channel inhibition did not prevent oxygen from constricting the immature sheep ductus at superphysiologic oxygen concentrations (Fig. 4A). Therefore, we speculate that other mechanisms may play a more significant role in the diminished responsiveness of the immature ductus to oxygen. These may include increased $\mathrm{K}_{\mathrm{Ca}}$ and $\mathrm{K}_{\mathrm{ATP}}$ activity (Fig. 4$)$, impaired calcium $\left[\mathrm{Ca}_{\mathrm{L}}(2,21)\right.$ or store-operated (17)] channel function, decreased rho kinase activity $(2,15-$ $17,21)$, decreased endothelin production (22), and/or increased sensitivity to prostaglandins and nitric oxide $(14,23,24)$.

Acknowledgments. We are grateful to Christine Roman, Naoko Brown, Jackie Coalson, Vicki Winter, personnel at the BPD Resource Centre, Alan Jobe, Machiko Ikegami, and John Newnham for help in obtaining tissues.

\section{REFERENCES}

1. Nakanishi T, Gu H, Hagiwara N, Momma K 1993 Mechanisms of oxygen-induced contraction of ductus arteriosus isolated from the fetal rabbit. Circ Res 72:12181228

2. Clyman RI, Waleh NS, Kajino H, Roman C, Mauray F 2007 Calcium-dependent and calcium-sensitizing pathways in the mature and immature ductus arteriosus. Am J Physiol Regul Integr Comp Physiol 293:R1650-R1656

3. Tristani-Firouzi M, Reeve HL, Tolarova S, Weir EK, Archer SL 1996 Oxygeninduced constriction of rabbit ductus arteriosus occurs via inhibition of a 4-aminopyridine-, voltage-sensitive potassium channel. J Clin Invest 98:1959-1965
4. Thebaud B, Michelakis ED, Wu XC, Moudgil R, Kuzyk M, Dyck JR, Harry G, Hashimoto K, Haromy A, Rebeyka I, Archer SL 2004 Oxygen-sensitive Kv channel gene transfer confers oxygen responsiveness to preterm rabbit and remodeled human ductus arteriosus: implications for infants with patent ductus arteriosus. Circulation 110:1372-1379

5. Hayama E, Imamura S, Wu C, Nakazawa M, Matsuoka R, Nakanishi T 2006 Analysis of voltage-gated potassium channel betal subunits in the porcine neonatal ductus arteriosus. Pediatr Res 59:167-174

6. Park MK, Lee SH, Lee SJ, Ho WK, Earm YE 1995 Different modulation of $\mathrm{Ca}$-activated $\mathrm{K}$ channels by the intracellular redox potential in pulmonary and ear arterial smooth muscle cells of the rabbit. Pflugers Arch 430:308-314

7. Yuan JX 2001 Oxygen-sensitive $\mathrm{K}(+)$ channel(s): where and what? Am J Physiol Lung Cell Mol Physiol 281:L1345-L1349

8. Brayden JE 2002 Functional roles of KATP channels in vascular smooth muscle. Clin Exp Pharmacol Physiol 29:312-316

9. Liu Y, Gutterman DD 2002 Oxidative stress and potassium channel function. Clin Exp Pharmacol Physiol 29:305-311

10. Korovkina VP, England SK 2002 Molecular diversity of vascular potassium channel isoforms. Clin Exp Pharmacol Physiol 29:317-323

11. Kajino H, Chen YQ, Seidner SR, Waleh N, Mauray F, Roman C, Chemtob S, Koch CJ, Clyman RI 2001 Factors that increase the contractile tone of the Ductus Arteriosus also regulate its anatomic remodeling. Am J Physiol Regul Integr Comp Physiol 281:R291-R301

12. Clyman RI, Chan CY, Mauray F, Chen YQ, Cox W, Seidner SR, Lord EM, Weiss H, Wale N, Evan SM, Koch CJ 1999 Permanent anatomic closure of the ductus arteriosus in newborn baboons: the roles of postnatal constriction, hypoxia, and gestation. Pediatr Res 45:19-29

13. Nelson MT, Quayle JM 1995 Physiological roles and properties of potassium channels in arterial smooth muscle. Am J Physiol 268:C799-C822

14. Waleh N, Kajino H, Marrache AM, Ginzinger D, Roman C, Seidner SR, Moss TJ, Fouron JC, Vazquez-Tello A, Chemtob S, Clyman RI 2004 Prostaglandin E2mediated relaxation of the ductus arteriosus: effects of gestational age on g proteincoupled receptor expression, signaling, and vasomotor control. Circulation 110:2326-2332

15. Costa M, Barogi S, Socci ND, Angeloni D, Maffei M, Baragatti B, Chiellini C, Grasso E, Coceani F 2006 Gene expression in ductus arteriosus and aorta: comparison of birth and oxygen effects. Physiol Genomics 25:250-262

16. Kajimoto H, Hashimoto K, Bonnet SN, Haromy A, Harry G, Moudgil R, Nakanishi T, Rebeyka I, Thebaud B, Michelakis ED, Archer SL 2007 Oxygen activates the Rho/Rho-kinase pathway and induces RhoB and ROCK-1 expression in human and rabbit ductus arteriosus by increasing mitochondria-derived reactive oxygen species. A newly recognized mechanism for sustaining ductal constriction. Circulation 115:1777-1788

17. Hong Z, Hong F, Olschewski A, Cabrera JA, Varghese A, Nelson DP, Weir EK 2006 Role of store-operated calcium channels and calcium sensitization in normoxic contraction of the ductus arteriosus. Circulation 114:1372-1379

18. Roulet MJ, Coburn RF 1981 Oxygen-induced contraction in the guinea pig neonatal ductus arteriosus. Circ Res 49:997-1002

19. Michelakis E, Rebeyka I, Bateson J, Olley P, Puttagunta L, Archer S 2000 Voltagegated potassium channels in human ductus arteriosus. Lancet 356:134-137

20. Wu C, Hayama E, Imamura S, Matsuoka R, Nakanishi T 2007 Developmental changes in the expression of voltage-gated potassium channels in the ductus arteriosus of the fetal rat. Heart Vessels 22:34-40

21. Thebaud B, Wu XC, Kajimoto H, Bonnet S, Hashimoto K, Michelakis ED, Archer SL 2008 Developmental absence of the $\mathrm{O}_{2}$ sensitivity of L-type calcium channels in preterm ductus arteriosus smooth muscle cells impairs $\mathrm{O}_{2}$ constriction contributing to patent ductus arteriosus. Pediatr Res 63:176-181

22. Coceani F, Armstrong C, Kelsey L 1989 Endothelin is a potent constrictor of the lamb ductus arteriosus. Can J Physiol Pharmacol 67:902-904

23. Liu H, Manganiello V, Waleh N, Clyman RI 2008 Expression, activity and function of phosphodiesterases in the mature and immature ductus arteriosus. Pediatr Res 64:477-481

24. Seidner SR, Chen Y-Q, Oprysko PR, Mauray F, Tse MM, Lin E, Koch C, Clyman RI 2001 Combined prostaglandin and nitric oxide inhibition produces anatomic remodeling and closure of the ductus arteriosus in the premature newborn baboon. Pediatr Res 50:365-373 